\title{
IMPROVING ABILITY TO SPEAK THROUGH ROLE PLAYING ACTIVITIES IN STUDENTS OF TK PERTIWI NAMBANGAN I SELOGIRI
}

\author{
Heni Amrih Laksmita Dewi
}

TK Pertiwi Nambangan I Selogiri

henyamrihlaksmitadewi@gmail.com

\section{Article History}

accepted 09/07/2018

approved 01/08/2018

published 17/09/2018

\section{Keywords}

Kemampuan berbicara, Bermain peran.

\begin{abstract}
Penelitian ini dilakukan dengan tujuan untuk meningkatkan kemampuan berbicara melalui kegiatan bermain peran pada peserta didik kelompok A.2 TK Pertiwi Nambangan I Kecamatan Selogiri Semester I tahun pelajaran 2016/2017. Metode penelitian tindakan kelas ini dilakukan dalam dua siklus yang masing-masing meliputi tahap perencanaan, tahap pelaksanaan tindakan, tahap hasil pengamatan serta tahap refleksi. Pelaksanaan penelitian di TK Pertiwi Nambangan I Selogiri dimulai minggu terakhir bulan Juli sampai dengan minggu terakhir bulan Oktober selama 14 minggu dengan subyek penelitian peserta didik kelompok A.2 sejumlah 16 anak. Hasil penelitian menunjukkan bahwa melalui kegiatan bermain peran dapat meningkatkan kemampuan berbicara pada anak didik kelompok A.2 TK Pertiwi Nambangan I Kecamatan Selogiri semester I tahun pelajaran 2017/2018.
\end{abstract}

Social, Humanities, and Education Studies (SHEs): Conference Series https://jurnal.uns.ac.id/shes
p-ISSN 2620-9284

e-ISSN 2620-9292 


\section{PENDAHULUAN}

Masa usia dini merupakan masa anak mulai mengenal diri dan lingkungannya. Masa usia dini merupakan masa berlangsungnya proses pendidikan, yaitu sejak anak berada dalam kandungan, masa bayi hingga anak berumur enam tahun. Masa usia dini merupakan masa keemasan untuk mengembangkan berbagai aspek kemampuan anak dengan memberikan berbagai rangsangan atau stimulasi yang positif. Usia dini merupakan usia anak membutuhkan berbagai stimulasi yang positif yang dapat diberikan baik dari keluarga maupun lingkungan sekitarnya. Anak usia dini memiliki pertumbuhan dan perkembangan yang berbeda dengan anak yang usianya di atas enam tahun baik dari segi fisik, emosi, kreativitas, bahasa dan sosial.

Banyak aspek kemampuan dalam diri anak yang perlu mendapat stimulasi agar dapat teraktualisasikan. Kemampuan berbahasa khususnya kemampuan berbicara merupakan salah satu kemampuan yang harus dikembangkan pada usia dini selain kemampuan dasar lain yang dimiliki anak yaitu kognitif, fisik motorik, sosial emosional. Kemampuan berbicara memungkinkan manusia untuk dapat saling berkomunikasi, baik mengkomunikasikan pikiran, perasaan maupun sikap dan dengan bahasa pula manusia dapat meningkatkan kemampuan intelektual. Tanpa memiliki kemampuan berbicara, maka kegiatan berpikir secara sistematis dan teratur tidak akan dapat dilakukan. Tanpa bahasa manusia juga tidak akan dapat mengembangkan diri dan lingkungannya, karena tanpa bahasa tidak dapat mengkomunikasikan pengetahuan yang dimiliki pada orang lain.

Salah satu tujuan dari program pendidikan usia dini adalah perkembangan bahasa, terutama dalam berbicara karena dengan berbicara anak dapat menuangkan gagasan kepada orang lain. Dalam perkembangan bahasa peran guru sangat diperlukan untuk merangsang anak, hal ini sangat penting karena dengan berbicara anak dapat bersosialisasi dengan teman, guru dan lingkungannya. Karena pentingnya perkembangan bahasa ini maka dalam setiap pembelajaran anak usia dini khususnya di Taman Kanak-kanak diberikan setiap hari salah satunya yaitu berbagi pengalaman kepada teman tujuan kegiatan berbagi pengalaman tersebut adalah agar anak mampu berbicara dengan baik dan dapat melatih keberanian.

Di Taman Kanak-kanak Pertiwi Nambangan I Kecamatan Selogiri anak anak mengalami kesulitan untuk berbicara dengan baik, penyebab dari masalah sulitnya mengungkapkan gagasan atau ide apakah dikarenakan awal tahun pelajaran sehingga anak masih dalam masa penyesuaian diri dengan lingkungan sekolah karena anak masih membutuhkan waktu untuk melatih keberanian untuk berbicara faktor lain yang menyebabkan anak belum mampu berbicara dengan baik disebabkan karena guru kurang memberikan rangsangan yang menarik, banyak anak yang tidak menjawab setiap ditanya guru, pada kegiatan berbagi pengalaman banyak anak yang berebut untuk mendapat giliran akan tetapi setelah diberi waktu anak hanya diam dan hal tersebut berlangsung setiap hari maka guru segera mengambil tindakan dikarenakan dari 16 anak belum ada anak yang berkembang sangat baik ( BSB ) kemampuannya dalam berbicara yaitu sebesar $0 \%$ sejumlah 1 anak yang berkembang sesuai harapan ( $\mathrm{BSH}$ ) dalam berbicara, sebesar $6 \%, 3$ anak mulai berkembang ( MB ) dalam berbicara, sebesar $19 \%$ dan 12 anak belum berkembang ( BB ) dalam berbicara, sebesar $75 \%$ bila hal ini dibiarkan maka kemampuan berbicara anak TK Pertiwi Nambangan 1 Kecamatan Selogiri rendah.

Untuk meningkatkan kemampuan berbicara guru perlu menciptakan kegiatan yang menarik minat anak agar anak termotivasi untuk berbicara. Karena salah satu lingkup pengembangan di Taman Kanak-kanak salah satunya yang dikembangkan adalah pengembangan bahasa yaitu dalam kompetensi inti 4 yaitu menunjukkan yang diketahui, dirasakan, dibutuhkan, dan dipikirkan melalui bahasa, musik, gerakan dan karya secara produktif dan kreatif, serta mencerminkan perilaku anak berakhlak mulia 
dan dalam kompetensi dasar no 4.11 yang berbunyi menunjukkan kemampuan berbahasa ekspresif ( mengungkapkan bahasa secara verbal dan non verbal ).

Kemampuan berbicara diharapkan meningkat namun demikian dalam kegiatan berbicara guru belum menemukan kegiatan yang menarik minat anak agar dapat lebih terampil berbahasa, guru kurang merangsang ide anak untuk berbicara, anak kurang keberanian untuk berbicara, anak kurang ide dalam berbicara. Dengan kondisi seperti ini maka muncul masalah yaitu kemampuan berbicara rendah pada peserta didik kelompok A.2 Taman Kanak-kanak Pertiwi Nambangan I semester I tahun pelajaran 2017/2018.

Untuk mengatasi masalah rendahnya kemampuan anak dalam berbicara perlu dilakukan tindakan yang dapat meningkatkan minat anak dan anak dapat berbicara dengan baik, terampil, berani. Rencana tindakan yang akan dilakukan untuk mengatasi masalah tersebut yaitu dengan kegiatan bermain peran, dengan kegiatan ini anak dapat termotivasi idenya untuk berbicara dengan temannya, anak akan saling memberi rangsangan antara teman yang satu dengan yang lainnya. Kegiatan bermain peran dipilih karena kegiatan bermain peran menarik, sangat dekat dengan anak, sederhana, mudah dilakukan dan dimengerti anak, dan guru mudah dalam menyiapkan peralatannya, guru mudah untuk melakukan pengamatan terhadap anak karena kegiatan bermain peran dilakukan dalam satu ruang bahkan dalam satu kelompok kecil.

Dari uraian di atas maka dapat diasumsikan bahwa kegiatan bermain peran dapat meningkatkan kemampuan berbicara yang sebelumnya banyak anak yang mendapatkan nilai belum berkembang diharapkan nilai anak meningkat pada berkembang sesuai harapan dan berkembang sangat baik maka dapat ditarik kesimpulan bahwa dengan kegiatan bermain peran dapat meningkatkan kemampuan berbicara pada peserta didik kelompok A.2 Taman Kanak-kanak Pertiwi Nambangan I Kecamatan Selogiri Semester I Tahun Pelajaran 2017/2018.

Rumusan masalah pada penelitian tindakan kelas ini adalah : "Apakah kemampuan berbicara dapat ditingkatkan melalui kegiatan bermain peran pada peserta didik kelompok A.2 Taman Kanak-kanak Pertiwi Nambangan I semester I tahun pelajaran 2017/2018?"

Tujuan penelitian ini adalah untuk meningkatkan kemampuan berbicara melalui kegiatan bermain peran pada peserta didik kelompok A.2 Taman Kanak-kanak Pertiwi Nambangan I semester I tahun pelajaran 2017/2018.

Kajian Teori

Anak dapat berkomunikasi dengan orang lain karena bahasa, dengan berkomunikasi dengan orang lain maka anak akan banyak mendapat kosakata atau perbendaharaan kata, sekaligus anak dapat mengekspresikan dirinya. Ketika anak belajar untuk menyimak dan berbicara, anak akan beraltih mengontrol dirinya sendiri dan lingkungannya, berhubungan secara efektif dengan orang lain mendapatkan dan menyimpan informasi yang lebih banyak. Melalui kemampuan berbahasa anak dapat melibatkan diri dalam sejumlah percakapan. Mereka menggunakan bahasa dengan berbagai cara, termasuk bertanya, dialog, bernyanyi dan syair. Penggunaan bahasa oleh anak sangat berhubungan dengan persepsi mereka terhadap dunia sekelilingnya, mereka menggunakan bahasa untuk bereksperimen.

Aspek bahasa dapat dibagi menajdi dua jenis yaitu aspek reseptif dan aspek ekspresif/produktif. Jika ditinjau dari cara penyampaiannya maka aspek bahasa dibedakan menjadi dua yaitu secara lisan dan secara tertulis. Aspek reseptif (menerima informasi) bahasa meliputi keterampilan menyimak dan membaca. Aspek ekspresif/produktif (menyampaikan informasi) bahasa meliputi keterampilan berbicara dan menulis. Sehingga antara kemampuan mengungkapkan bahasa berkaitan dengan dengan berbicara. 
Menurut Yeti Mulyati sebagaimana mengutip pendapat Suhendar ( 1992: 2 ) mendefinisikan bahwa berbicara adalah kegiatan menyampaikan pesan kepada orang lain dengan media bahasa lisan dan berbicara adalah perubahan wujud pikiran/perasaan menjadi wujud ujaran.

Kemampuan berbicara dan juga dapat dikaitkan dengan kemampuan berbicara adalah diharapkan anak mampu melibatkan diri dalam sejumlah percakapan. Anak boleh mengunakan bahasa dengan berbagai cara.

Kemampuan berbicara yang berkembang setelah kemampuan mendengar adalah kemampuan berbicara. Ketika kita mengajak anak berbicara maka anak akan menyerap semua kata-kata yang kita ucapkan. Jalongo menerangkan bahwa berbicara berkaitan dengan interaksi sosial. Untuk mengembangkan kemampuan berbicara dapat dilakukan dengan merancang pembelajaran yang melibatkan anak dalam interaksi sosial.

Menurut Tadkiroatun Musfiroh sebagaimana mengutip pendapat Lwin, el.al., (2005) mendefinisikan bahwa berbicara dapat diartikan sebagai kemampuan menyelesaikan masalah mengembangkan masalah, dan menciptakan sesuatu dengan menggunakan bahasa secara efektif, baik lisan maupun tertulis. berbicara yaitu kemampuan untuk menyusun pikiran dengan jelas dan mampu menggunakan kemampuan ini secara kompeten melalui kata-kata untuk mengungkapkan pikiranpikiran ini dalam berbicara, membaca dan menulis .

Berdasarkan beberapa teori di atas dapat disimpulkan bahwa kemampuan berbicara adalah kemampuan seseorang untuk mengungkapkan pikirannya, perasaanya agar di mengerti orang lain, sebagai alat untuk berkomunikasi dengan individu lain, dengan kemampuan berbicara seseorang dapat mendapatkan pengalaman yang beragam, dapat diterima di lingkungan sosial dan mendukung prestasi akademik lainnya dan untuk mendapatkan kemampuan berbicara tersebut seseorang harus mendapatkan kesempatan untuk mengekspresikannya, melukiskannya dan memanipulasinya. Kemampuan berbicara adalah kemampuan menyelesaikan masalah mengembangkan masalah, dan menciptakan sesuatu dengan menggunakan bahasa secara efektif, baik lisan maupun tertulis. Kemampuan berbicara adalah kemampuan untuk menyusun pikiran dengan jelas dan mampu menggunakan kemampuan ini secara kompeten melalui kata-kata untuk mengungkapkan pikiranpikiran.

Beberapa hal yang berpengaruh terhadap kemampuan berbicara menurut Yeti Mulyati (2009 : 2.14) sebagaimana mengutip pendapat Maidar Arsjad dan Mukti U.S. ada beberapa faktor yang mempengaruhi kemampuan berbicara yaitu 1). Keberanian dalam berbicara adalah kemampuan mengemukakan pendapat dan keberpihakan pada gagasan yang diyakini kebenarannya, 2). Kelancaran menurut Yeti Mulyati (2009 : 2.14) sebagaimana mengutip pendapat Nurgiyantoro (1988: 261) mengungkapkan beberapa hal yang menunjukkan ketidaklancaran dalam berbicara, yaitu : a). Pembicaraan selalu terhenti dan terputus-putus, b). Pembicaraan sangat lambat dan sering tampak ragu pada kalimat yang diucapkannya, c). Kenyaringan suara bukanlah suara yang keras akan tetapi suara yang efektif yaitu apakah oranng yang paling jauh dengan kita dapat mendengar kita dengan jelas, d). Pandangan mata arah pandangan mata adalah menatap lawan bicara tidak menunduk atau menengadah, e). Gerak-gerik dan mimik, gerak-gerik dan mimik diperlukan untuk mendukung penjelasan verbalisme, gerak-gerik dan mimik juga tidak boleh berlebihan, f). Penalaran pembicaraan yang diungkapkan harus masuk akal, g). Sikap yang wajar dalam mengungkapkan bahasa dibutuhkan sikap tenang, wajar dan tidak kaku dan tidak dibuat-buat.

Bermain adalah melakukan kegiatan yang disengaja, dilakukan sendiri, berpasangan, bersama, bermain adalah kegiatan yang menyenangkan.Peran diartikan sebagai suatu rangkaian perasaan, ucapan dan tindakan individu yang ditujukan kepada orang lain. Peran seseorang dalam kehidupan dipengaruhi oleh persepsi dan 
penilaian oleh dirinya dan orang lain. Untuk dapat berperan dengan baik, diperlukan pemahaman tentang peran sendiri mencakup apa yang tampak dan tindakan yang tersembunyi dalam perasaan, persepsi dan sikap. Esensi bermain peran ditujukan untuk membantu individu untuk memahami perannya sendiri dan peran yang dimainkan orang lain sekaligus berupaya memahami perasaan, sikap dan nilai-nilai yang mendasarinya. Pada dasarnya ide utama dari bermain peran adalah untuk menjadi "sosok" individu yang diperankan dan untuk mendapatkan pemahaman tentang peran tersebut dan motivasi yang berkaitan. Kegiatan ini dapat melibatkan jumlah anak yang terbatas dalam interaksi berpasangan atau beberapa anak dalam kelompok kecil.

Bermain peran adalah metode belajar yang berumpun pada metode perilaku yang diterapkan dalam kegiatan pengembangan. Karakteristiknya adalah adanya kecenderungan memecahkan tugas belajar adalam sejumlah perilaku yang berurutan, konkret dan dapat diamati.

Menurut Winda Gunarti ( 2008 : 10.9) sebagaimana mengutip pendapat Gilstrap dan Martin mengatakan bahwa bermain peran adalah memerankan karakter/tingkah laku dalam pengulangan kejadian yang diulang kembali, kejadian masa depan, kejadian masa kini yang penting, atau situasi imajinatif yang penting. Anak-anak pemeran mencoba untuk menjadi orang lain dengan memahami peran untuk menghayati tokoh yang diperankan sesuai dengan karakter dan motivasi yang dibentuk pada tokoh yang telah ditentukan.

Menurut Winda Gunarti ( 2008 : 10.9) sebagaimana mengutip pendapat Supriyati mengatakan bahwa bermain peran adalah permainan yang memerankan tokoh-tokoh atau benda-benda sekitar anak sehingga dapat mengembangkan daya khayal (imajinasi) dan penghayatan terhadap bahan kegiatan yang dilaksanakan. Bermain peran berarti menjalankan fungsi sebagai orang yang dimainkannya, misalnya berperan sebagai dokter, ibu guru, nenek tua renta.

Menurut Winda Gunarti (2008 : 10.10) sebagaimana mengutip pengertian bermain peran menurut buku Didaktik Metodik di Taman Kanak-kanak (Depdikbud 1998) bahwa bermain peran adalah memerankan tokoh-tokoh atau benda-benda disekitar anak dengan tujuan untuk mengembangkan daya khayal (imajinasi) dan penghayatan terhadap bahan pengembangan yang dilaksanakan.

Bermain peran sering digunakan untuk mengajarkan masalah tanggung jawab warga negara, kehidupan sosial atau konseling kelompok. Dengan bermain peran memberi kesempatan kepada anak untuk mempelajari tingkah laku manusia. Anak dapat mengeksplorasi perasaan mereka, menghayati persepsi dan tingkah laku orang lain dan belajar terlibat dan berinteraksi dalam proses pembuatan keputusan. Bermain peran juga mengajarkan bagaimana membuat keputusan bersama dan juga mengajarkan anak untuk belajar melalui dramatisasi.

Dengan demikian dapat disimpulkan bahwa bahwa bermain peran adalah metode belajar yang berumpun pada metode perilaku yang diterapkan dalam kegiatan pengembangan. Karakteristiknya adalah adanya kecenderungan memecahkan tugas belajar adalam sejumlah perilaku yang berurutan, konkret dan dapat diamati. Bermain peran adalah memerankan karakter/tingkah laku dalam pengulangan kejadian yang diulang kembali, kejadian masa depan, kejadian masa kini yang penting, atau situasi imajinatif yang penting. Bermain peran adalah permainan yang memerankan tokohtokoh atau benda-benda sekitar anak sehingga dapat mengembangkan daya khayal (imajinasi) dan penghayatan terhadap bahan kegiatan yang dilaksanakan. Bermain peran adalah untuk menjadi "sosok" individu yang diperankan dan untuk mendapatkan pemahaman tentang peran tersebut dan motivasi yang berkaitan

Menurut Winda Gunarti sebagaimana mengutip pendapat Fledman, J.R (1997) mengatakan bahwa beberapa manfaat bermain peran anak dapat mempraktikkan kemampuan berbicara dengan bermain peran anak dapat mempelajari dirinya sendiri, 
keluarga dan masyarakat sekitarnya. Mereka menjalankan perannya berdasarkan pengalamannya yang terdahulu. Anak belajar memutuskan dan memilih berbagai informasi yang relevan. Anak juga dapat berkonsentrasi dalam satu tema drama dalam waktu tertentu. Dengan bermain peran dapat memberikan ruang imajinasi pada anak.

Menurut Winda Gunarti (2008 : 10.11) mengatakan bahwa bermain peran mempunyai tujuan yaitu ; a) Anak dapat mengekspolorsi perasaan-perasaan, b). Memperoleh wawasan tentang sikap-sikap, nilai-nilai dan persepsinya, c). Melatih daya tangkap, d). Melatih daya konsentrasi, e). Mencapai kemampuan komunikasi secara spontan/berbicara lancar, f). Membangun pemikiran yang analitis dan kritis, g). Membangun sikap positif pada diri anak, h). Menumbuhkan sikap afektif melalui penghayatan isi cerita, i). Untuk membawa situasi yang sebenarnya ke dalam bentuk stimulasi/miniatur kehidupan

\section{METODE PENELITIAN}

Penelitian ini dilaksanakan pada semester I tahun pelajaran 2017/2018 dilaksanakan minggu terakhir bulan Juli sampai dengan minggu terakhir bulan Oktober tahun 2016 selama 14 minggu. Penentuan waktu penelitian ini mengacu pada kalender pendidikan dengan alokasi waktu pembelajaran pada bulan 2015. Penelitian ini dilakukan di TK Pertiwi Nambangan I Kecamatan Selogiri Kabupaten Wonogiri, pada kelompok A.2 semester I tahun pelajaran 2016/2017. Dengan pertimbangan peneliti bertugas sebagai guru di kelompok tersebut. Subjek dalam penelitian tindakan kelas ini adalah peserta didik pada kelompok A.2 di TK Pertiwi Nambangan 1 Kecamatan Selogiri. Peserta didik berjumlah 16 anak yang terdiri dari 7 anak laki-laki dan 9 anak perempuan. Data yang digunakan dalam penelitian ini yaitu : 1). Peserta didik, berkaitan dengan kemampuan berbicara saat melaksanakan kegiatan bermain peran, 2). Teman sejawat, berdasarkan hasil pengamatanan serta hasil wawancara dalam mengamati proses perilaku belajar peserta didik, 3). Dokumen atau arsip antara lain kurikulum, rencana pembelajaran, buku penilaian.

Penelitian dikatakan berhasil dan dapat dihentikan apabila minimal $70 \%$ dari jumlah siswa mendapatkan nilai BSH dan BSB dari lembar observasi kemampuan berbicara anak. Teknik analisis data menggunakan analisis diskriptif yaitu metode yang menjelaskan dan melaksanakan perbandingan hasil belajar sebelum siklus dibandingkan dengan hasil belajar setelah siklus I, hasil belajar pada siklus I dibandingkan dengan hasil belajar setelah siklus II.

Penelitian ini dilakukan dalam 2 siklus yang masing-masing siklus meliputi 4 tahap yaitu tahap perencanaan, tahap pelaksanaan, tahap pengamatan, dan tahap refleksi.

\section{a. Diskripsi Kondisi Awal}

\section{HASIL PENELITIAN DAN PEMBAHASAN}

Kemampuan berbicara di Taman Kanak-kanak Pertiwi Nambangan I Kecamatan Selogiri pada awal tahun pelajaran 2017/2018 peserta didik mengalami kesulitan untuk berbicara dengan lancar hal ini disebabkan karena guru kurang memberikan kegiatan yang menarik minat anak untuk dapat mengungkapkan gagasan atau idenya untuk berbicara, banyak anak yang tidak menjawab setiap ditanya guru, pada kegiatan berbagi pengalaman banyak anak yang berebut untuk mendapat giliran akan tetapi setelah diberi waktu anak hanya diam dan hal tersebut berlangsung setiap hari dalam waktu kurang lebih 1 bulan anak masih belum mampu untuk mengungkapkan bahasa dengan baik, bahkan dari 16 anak belum ada anak yang berkembang sangat baik ( BSB ) kemampuannya dalam berbicara yaitu sebesar 0\% sejumlah 1 anak yang berkembang sesuai harapan ( $\mathrm{BSH}$ ) dalam berbicara, sebesar 6 $\%$, 3 anak mulai berkembang ( MB ) dalam berbicara, sebesar $19 \%$ dan 12 anak 
belum berkembang ( $\mathrm{BB}$ ) dalam berbicara, sebesar $75 \%$ bila hal ini dibiarkan maka kemampuan berbicara anak TK Pertiwi Nambangan I Kecamatan Selogiri rendah.

Berdasarkan hasil pengamatan pada proses pembelajaran kemampuan berbicara peserta didik pada kondisi awal masih rendah. Berdasarkan penilaian hasil belajar peserta didik pada kegiatan pembelajaran kemampuan berbicara kompetensi inti (KI 3) yaitu mengenali diri, keluarga, teman, pendidik dan/atau pengasuh, lingkungan sekitar, teknologi, seni, dan budaya di rumah, tempat bermain dan satuan PAUD dengan cara: mengamati dengan indera (melihat, mendengar, menghidu, merasa, meraba); menanya : mengumpulkan informasi; mengolah informasi/mengasosiasikan, dan mengkomunikasikan melalui kegiatan bermain dan kompetensi dasar (KD) no 3.11 yaitu memahami bahasa ekspresi (mengungkapkan bahasa secara verbal dan nonverbal) dari 16 anak belum ada anak yang berkembang sangat baik ( BSB ), kemampuannya dalam berbicara yaitu sebesar $0 \%$. Sejumlah 1 anak yang berkembang sesuai harapan ( $\mathrm{BSH}$ ) dalam berbicara sebesar $6 \%$. Dan 3 anak mulai berkembang ( MB ) dalam berbicara sebesar $19 \%$ dan 12 anak belum berkembang ( BB ) dalam berbicara sebesar $75 \%$.

\section{b.Diskripsi Siklus I}

Perencanaan Tindakan

Berdasarkan pengamatan sebelum tindakan pada kegiatan mengungkapkan bahasa minat anak rendah karena guru belum menggunakan kegiatan yang merangsang minat anak untuk berbicara. Untuk mengatasi masalah yang muncul, peneliti akan menggunakan kegiatan bermain peran dalam kegiatan meningkatkan kemampuan berbicara. Menyusun Rencana Pelaksanaan Pembelajaran Harian (RPPH), membuat Rencana Pelaksanaan Pembelajaran Harian (RPPH) untuk 3 kali pertemuan berdasarkan RPPH dimulai hari Kamis, tanggal 1 - 3 September 2016. Membuat instrumen penilaian yaitu observasi dan unjuk kerja. 1). Menyiapkan materi, 2). Menyiapkan peralatan kegiatan bermain peran sesuai dengan sub tema., 3). Membuat lembar pengamatan tentang kelancaran berbicara, keberanian dalam mengungkapkan ide dan keaktifan dalam bermain peran.

Berdasarkan hasil pengamatan selama proses pembelajaran peserta didik terlihat agak semangat dan aktif dalam mengikuti kegiatan bermain peran. Anak mulai saling berbicara dengan bahasanya sendiri meskipun dengan suara yang pelan dan belum begitu lancar. Anak belum melakukan dialog dengan teman mereka, anak-anak cenderung berbicara sendiri-sendiri. Namun demikian keberanian untuk mengungkapkan ide untuk memerankan sesuai dengan tema mulai muncul.

Berdasarkan hasil pengamatan pada proses belajar peserta didik pada saat kegiatan bermain peran untuk meningkatkan kemampuan berbicara dengan judul aku sayang adik, sebagian anak sudah mampu menceritakan sesuai dengan tema. Dari 16 peserta didik baru 1 anak yang mendapatkan nilai berkembang sangat baik (BSB) sebesar $6 \%$, sejumlah 3 anak mendapat nilai berkembang sesuai harapan (BSH) sebesar $19 \%$, sejumlah 4 anak mendapatkan nilai mulai berkembang ( MB ) sebesar $25 \%$, dan lainnya sejumlah 8 anak mendapat nilai belum berkembang ( BB ) sebesar $50 \%$. 


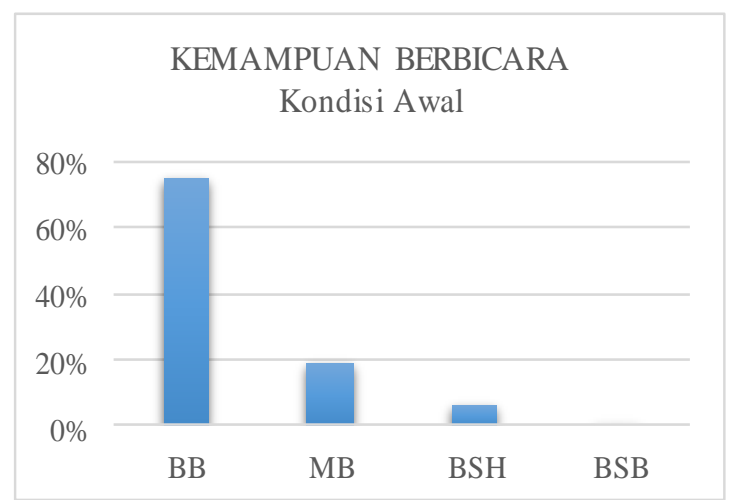

Pada saat proses pembelajaran keaktifan anak sedikit meningkat anak menjadi senang berbicara melalui kegiatan bermain peran. Keberanian dalam mengungkapkan ide gagasan untuk berbicara mulai meningkat dari rendah ke sedang. Hasil belajar peserta didik sudah mulai meningkat dari kondisi awal saat pembelajaran mengungkapkan bahasa semula belum berkembang sejumlah 12 anak yang belum mencapai TPP menurun menjadi 8 anak yang belum mencapai TPP, mulai berkembang pada kondisi awal hanya 3 anak juga mengalami peningkatan menjadi 4 anak, berkembang sesuai harapan mengalami peningkatan pada kondisi awal hanya 1 anak menjadi 3 anak, sedangkan yang berkembang sangat baik meningkat menjadi 1 anak, dari hasil siklus I masih perlu diadakan perbaikan pembelajaran pada siklus II.

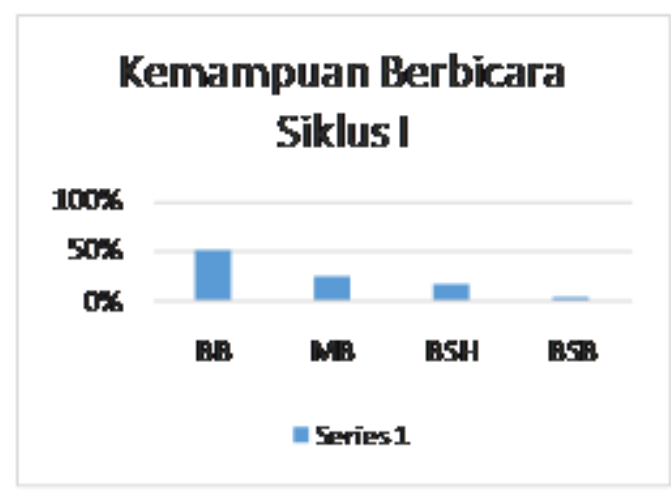

\section{c. Diskripsi Siklus II}

Pada siklus II selama proses pembelajaran dan hasil belajar peserta didik menjadi tinggi, peserta didik lebih aktif dan motivasi anak sangat tinggi. Hasil belajar peserta didik menjadi meningkat dari 16 anak berkembang sangat baik BSB sejumah 8 anak sebesar $50 \%$, berkembang sesuai harapan BSH sejumlah 5 anak sebesar $31 \%$, mulai berkembang MB sejumlah 2 anak sebesar 13\% dan belum berkembang BB sejumah 1 anak sebesar $6 \%$ sehingga masih 6\% yang masih perlu bimbingan. Dengan bermain peran pada siklus II ini anak lebih tertarik untuk berbicara, sehingga peneliti merasa cukup dalam melaksanakan perbaikan pembelajaran.

\section{PEMBAHASAN}

Perkembangan perilaku peserta didik selama proses pembelajaran pada kondisi awal, kelancaran berbicara, keberanian dalam mengungkapkan ide dan keaktifan dalam bermain peran masih rendah, pada siklus I perilaku belajar peserta didik dalam keaktifan dalam bermain peran, kelancaran berbicara, keberanian dalam mengungkapkan ide dan keaktifan dalam bermain peran meningkat. Kemudian dilakukan perbaikan pembelajaran pada siklus II, setelah kegiatan pembelajaran pada 
siklus II perilaku belajar peserta didik dalam kelancaran berbicara, keberanian dalam mengungkapkan ide dan keaktifan dalam bermain peran menjadi lebih tinggi.

Perkembangan indikator kinerja berdasarkan hasil belajar peserta didik dari 16 peserta didik saat dilakukan perbaikan pada siklus I, sudah mengalami peningkatan dari 1 anak sebesar 6\% pada kondisi awal mengalami peningkatan menjadi 4 anak sebesar $25 \%$ pada siklus I. Prosenatse sebesar $25 \%$ adalah hasil penggabungan nilai berkembang sesuai harapan BSH dan berkembang sangat baik BSB.

Kemudian ditingkatkan lagi pada perbaikan siklus II, peningkatan hasil yang dicapai dari siklus I sejumlah 4 anak sebesar $25 \%$ menjadi 13 anak sebesar $81 \%$ siklus II. Prosenatse sebesar $81 \%$ adalah hasil penggabungan nilai berkembang sesuai harapan BSH dan berkembang sangat baik BSB.

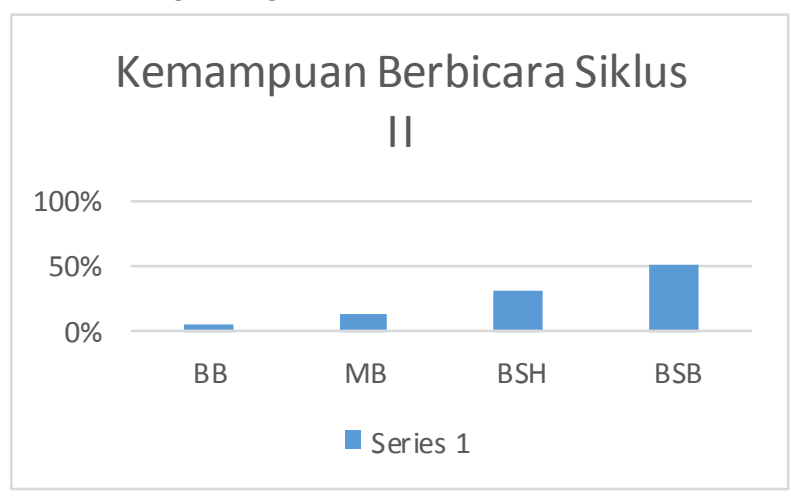

\section{SIMPULAN}

Berdasarkan hasil penelitian sebelum tindakan dan hasil setelah tindakan siklus I sampai dengan siklus II dan berdasarkan hasil pembahasan serta analisis yang telah dilaksanakan, dapat disimpulkan bahwa kemampuan berbicara peserta didik kelompok A.2 TK Pertiwi Nambangan I Kecamatan Selogiri Semester I tahun pelajaran 20167/2018.

Perkembangan indikator kinerja berdasarkan hasil belajar peserta didik dari 16 peserta didik saat dilakukan perbaikan pada siklus I, sudah mengalami peningkatan dari 1 anak sebesar 6\% pada kondisi awal mengalami peningkatan menjadi 4 anak sebesar $25 \%$ pada siklus I. Prosenatse sebesar $25 \%$ adalah hasil penggabungan nilai berkembang sesuai harapan BSH dan berkembang sangat baik BSB.

Kemudian ditingkatkan lagi pada perbaikan siklus II, peningkatan hasil yang dicapai dari siklus I sejumlah 4 anak sebesar $25 \%$ menjadi 13 anak sebesar $81 \%$ siklus II. Prosenatse sebesar $81 \%$ adalah hasil penggabungan nilai berkembang sesuai harapan $\mathrm{BSH}$ dan berkembang sangat baik BSB.

\section{DAFTAR PUSTAKA}

Ade Dwi Utami, dkk. 2014. Pendidikan Anak Usia Dini. Jakarta : Universitas Negeri Jakarta.

Deny Setiawan, dkk. 2011. Analisis Kegiatan Pengembangan Pendidikan Anak Usia Dini. Jakarta : Universita Terbuka.

IGAK Wardhani. 2008. Penelitian Tindakan Kelas. Jakarta: Universitas Terbuka.

Lara Fridani, dkk. 2011. Evaluasi Perkembangan Anak Usia Dini. Jakarta : Universitas Terbuka.

M. Toha Anggoro, dkk. 2008. Metode Penelitian. Jakarta: Universitas Terbuka. 
Sarwiji Suwandi. 2009. Penelitian Tindakan Kelas dan Penulisan Karya IImiah : Surakarta : Panitai Sertifikasi Guru.

Siti Aisyah. 2008. Perkembangan dan Konsep Dasar Pengembangan Anak Usia Dini. Jakarta: Universitas Terbuka.

Sutama. 2014. Penelitian Tindakan Kelas dan Penulisan Karya Ilmiah. Surakarta : FKIP-UMS

Tadkiroatun Musfiroh. 2008. Pengembangan Kecerdasan Majemuk. Jakarta: Universitas Terbuka.

Winda Gunarti, dkk. 2008. Metode Pengembangan Perilaku dan Kemampuan Dasar Anak Usia Dini. Jakarta : Universitas Terbuka.

Yeti Mulyati, dkk. 2009. Bahasa Indonesia. Jakarta: Universitas Terbuka. 